\title{
THE IMPACT OF LITHUANIAN FINANCIAL CRISIS FOR NATIONAL ECONOMY: COMPARATIVE STUDY
}

\author{
Deimena KiyaK ${ }^{1}$, Tomas Reichenbachas ${ }^{2}$ \\ Klaipeda University, Vilnius University (Lithuania)
}

\begin{abstract}
Emphasizing sustainable economic development preconditions in Lithuania and in order to research the formation of regional policy, the article was made on Lithuania financial crisis impact on the economy, comparative study. It was found that in the literature lacks of general method to compare the different financial crises that have occurred in different regions, countries or at different intervals impact to economic indicators, so was created financial crisis impact on countries economy index, to compare this diferent impact. The study identified three financial crisis which negatively affected Lithuanian economy - "Lithunia banking crisis" (1995), "Russian financial crisis" (1998) and "Global Financial Crisis" (2008). Based on this new index calculations, the financial crisis affect was compared and found that the greatest negative impact on the economy caused the Global financial crisis (2008). Examining the specifics of Lithuania's economy noted that all of the financial crisis affected the gross domestic product growth, labor market and the country budget balance. Meanwhile, the impact on other macroeconomic indicators of the crisis depended on the crises specifics and was different.

KEY WORDS: financial crisis, financial crisis index, the banking crisis, the Russian financial crisis, the global financial crisis.
\end{abstract}

JEL CODES: C180; G000; G010.

\section{Introduction}

The main problem in assessing the impact of financial crisis is the country's lack of comparability of economic indicators. If the financial crisis spill two countries it is possible to determine which country the crisis was more harmful (gross domestic product (GDP) shrinks, rise in unemployment and so on.). However, if the financial crisis on the conflicting data, for example, sharply fell in a country's GDP, but unemployment remained almost unchanged, while another country's unemployment rates has risen sharply, but GDP was almost not reduced - there is a financial crisis impact comparability problems. This problem becomes even greater when considering the larger number of economic indicators. Other highlights a lack of comparability between the developing countries compared to economic indicators during the financial crisis in developed ones. For example, strong GDP growth in the economy can just slow its growth rate, while in another country (developed) GDP may decline; in this case, there is a problem of comparability GDP changes. Consequently, to compare financial crisis impact on economy needs to evaluation of all the negative effects of into a single whole. For this you need an index to show the extent of the negative impact on the country's economy due to

1 Deimena Kiyak - Klaipeda University, Department of economics, social sciences, Assoc. Prof. Scientific interest: finance, accounting, pricing, financial and economic analysis.

E-mail: deimena@balticum-tv.lt

Tel.: +370682 20253 .

2 Tomas Reichenbachas - Vilnius University, master's degree student, social sciences, economy. Scientific interest: fnance, economy.

E-mail: treichenbachas@gmail.com

Tel.: +370 62051403 . 
financial crisis. Such an index would help to compare different types of financial crises on individual regions of the country, the country or even different countries.

The object of research: financial crisis impact on the country's economic performance.

The aim of research - to conduct a comparative study of the financial crisis impact on Lithuania's national economy.

The research objectives:

- To create the index which allows to compare financial crisis negative impact on economy.

- Approve reliability of this index.

- Calculate and compare the effects of financial crises to the Lithuania's economy index for the banking crisis, the Russian financial crisis and the global financial crisis.

Research methods: systematic literature analysis; statistical indicators clustering, comparison and summary; economic indicators analysis and synthesis, the financial crisis index creation and counting.

\section{Formation of financial crisis impact on the economy index}

During the last few decades world increasingly faces with problems of instability in the financial system (banking bankruptcies, stock market downturns, currency crises, etc.). Part of the financial crisis are local (Mexican peso crisis, 1995; Argentine peso devaluation and insolvency, 2001), other part - regional (Southeast Asian financial crisis, 1997), and another financial crisis transcends national and continental boundaries and become global (subprime mortgage crisis, 2008). Global financial systems in the world are closely linked, so the financial sector problems in one country strongly affects other countries. However, local and regional, and global financial crisis impact on economies differences.

While many authors produce many economic indicators to be affected by the financial crisis, but there is problem in assessing the impact of financial crises to the country economic problems, there is no single model of how to assess the financial crisis impact on the economy, and there is no methodology to compare this effects on the different countries. Klyviene et al. (1998) just do a comparison of key macroeconomic indicators (inflation dynamics, GDP growth, unemployment, etc.), Račickas et al. (2010), Kuodis et al. (2009), Denskyte (2010) examines in detail one particular financial crisis dynamic. However, such a comparison is not always enough. Consequently, to compare financial crisis impact on economy needs to evaluation of all the negative effects of into a single whole. For this you need an index to show the extent of financial crisis negative impact on the economy. Such an index would help to compare different types of financial crises on the country or different countries.

The scientific literature submitting, that financial crisis and economic downturn can last variety of time. The negative impact on GDP growth and other key indicators can last from several months to several decades. This depends on what type of financial crisis hit the country, how the country's public respond, international financial and economic support to a country (such as IMF support), etc. However, the authors Cerda (2009), Wyplosz (1998), Sachs (1996) state that the financial crisis usually lasts for 1-3 years, and the vast majority of them last no more than 5 years.

Fro mating financial crisis impact on the economy index $\left(X_{F K P E}\right)$, it is assumed that the negative impact of the country last no longer than 5 years and evaluate changes in national economic indicators: gross domestic product growth dynamics, changes in the labor market (unemployment rate and the "net" wage change); changes in the dynamics of inflation, current account balance change, and the credit market changes (changes in interest rates and credit growth dynamics); stock price index changes (deviation of the index from its peak before the crisis), the national budget balance changes. Before assessing these changes should be examined in detail how the financial crisis has affected them (primary inputs and logic-effect relationship). Thus, to avoid uncertainty, if the economy is not driven by a financial crisis, but also other economic processes (such as structural economic transformation). 
If, a logical analysis of the financial crisis shows that, financial crisis had a small (or even no) effect on economic indicator change, we do not include it in the calculation of the index (equals zero, assumption that deviation of this index is not a financial crisis impact on the economy).

Also, before calculating the financial crisis impact on the country's economy index $\left(X_{F K P E}\right)$, is esential to determine the initial starting point of the financial crisis, it is a date, we assume that the financial crisis began.

Assessing the economic indicators it is assumed that if there was no financial crisis impact, these indicators would have remained the same or their trend would be the same as before the financial crisis (for example, gross domestic product grow).

According Račickas et al. (2010), Sachs (1996), Mishkin (1992), Krugman (2008), Harvey (2010) GDP is one of the key indicators that reflect the economic level of a given area (usually the country). Gross domestic product is defined as the market value of all final goods and services produced within a certain period of time (usually years). GDP reflects the country's economic status and helps to identify the country's economic cycle. According to Wyplosz (1998), Harvey (2010), Krugman (2008) a consequence of the financial crisis are the economic recession (real GDP drop two quarters in a row). But the financial crisis could just cause a slowdown in economic growth. Effect on the country's GDP is highly dependent on economic growth before the financial crisis.

In order to assess the dynamics of GDP must be determined the former growth rate (before the financial crisis). For this purpose, we use "trend" function, and projecte country's GDP if the country would be untouched by the financial crisis. Comparing the predicted values and real GDP, the resulting negative impact is calculated as a percentage change between these values. Real GDP growth rate values calculated for five years after the start of the financial crisis, summed values obtained and the final result is identified $Y_{I B V P}$. If the calculation results in a situation that the actual GDP exceeds the forecast, this year's results are not cumulative, and equated to zero. Such a situation could arise if after a few years after the financial crisis, the economy is recovering faster than the growth before the financial crisis. This can happen if the financial crisis was much shorter than 5 years, or if the financial crisis on GDP was not significant. Also quick recovery is possible after economic stimulus, international investment. If in this situation cannot be determined former GDP growth rate and it's not possible to forecast GDP growth, then in the calculation it is used expected GDP loss, according to the situation.

Many authors (Račickas et al., 2010; Simonavičienès et al., 2009; Vetlov et al., 2006) argue that the financial crisis have significant impact on the labor market because of slowing economic growth, businesses faced with declining profits or even losses, and the result - decreasing wages or redundancy. Then economy is in a recession phase, the demand for labour generally decreases and unemployment increases. Growing unemployment increase labour supply and wages decline.

Changes in the labour during the financial crisis can be determined using the following algorithm: determining the average level of unemployment in the country before the financial crisis (five years before the financial crisis, the arithmetic mean, or if the unemployment rate has been stable or longer-term data are not available in the short period of 3 or 2 years), and subtracted from the resulting size of the actual unemployment level, during the financial crisis, and this data is summed. If there is a risk that after financial crisis during the five-year period unemployment rate can be lower than before the financial crisis, than this year is not included. The result is identified $Y_{\text {iun }}$.

In order to evaluate changes in wages we compare the former wages with post financial crisis wages. If a financial crisis at the beginning of earnings still rose, but later fell - the highest point would be the reference for a former wage. The resulting negative values between pre and post crisis wages summed up and calculated the percentage of pre-crisis net wages. This indicator is identified $-Y_{I W^{*}}$

The total financial crisis impact on the labor market indicator is expressed as $Y_{i l m}$ and calculated as the sum of $Y_{I W}$ and $Y_{\text {iun }}$.

During the financial crises often commodity (oil, gold, grains and others) prices becomes unstable, and it has a direct influence on price stability. Račickas et al. (2010), Mishkin (1992) argues that during the financial crises overvalued financial assets price drops significantly (most common it are stocks, real estate and 
raw materials). However, the raw materials needed for the production of basic goods prices tend to fall least. According to Harvey (2010) may result a situation then during financial crisis, inflation is rising. This may be due to commodity price appreciation, or the large capital inflows into the country's economy.

Inflation dynamics can be assessed by former five-year average inflation rate. If the inflation rate has been constant, or longer-term data are not available, can be used shorter period of 3 or 2 years. Former five-year average inflation rate is compared with the actual inflation rate five years after the financial crisis began. These changes are summed to give a rate of $Y_{i i}$, which can be both positive and negative, as inflation during the financial crisis can both increase and decrease, so these figures must be modulated (ie, only the absolute value is taken). The resulting index reflects the price stability, but not the price dynamics.

During the financial crises (especially in regional and global), the country's imports reduce and exports shows how the country's economy is dependent on the other countries' economies, as well as how country's economy is strongly affected by the financial crisis. According Daraškevičiūtės et al. (2007), analysing a small and open economies, the majority believed that the export recovery is one of the characters indicating the country's economic recovery. Therefore, the current account balance will be assessed on a current account balance for the year before the financial crisis and the current account balance for five years after the financial crisis erupted in the amount of difference. If this rate in any year is positive, ie the current account position has improved, it will not be cumulative. This indicator is expressed as $Y_{\text {iesd }}$.

The average interest rate - a financial indicator showing the average price of financial resources in the country which pays the country's economic units to which these resources is needed. It is accepted that during economic growth interest rate is higher than its long-term average, while the beginning of the economic downturn in the country, they are lower than the average long-term (often one of the factors influencing it central bank's policy). Most average interest rates in the country reflect the inter-bank interest rate indexes LIBOR (USD) and EURIBOR; EURLIBOR (EUR), VILIBOR (Lithuania). Commercial banks have issued loans to the country's residents or businesses to issue variable rates, which are associated with one of these indices (depending on the currency), and accompanied by the bank margin. However, such an assessment is not always accurate because of the financial crisis during the growing mistrust of business debt interest rates may increase, decrease, even in the interbank lending rate (due to the central bank), banks can increase their margins (as happened in 2008 and 1930, the Great Depression in the U.S.). According to, Kuodis et al. (2005) in small financial crisis-affected countries with currency board regime, the interest rate during the financial crisis is particularly unstable, can often occur because of high capital outflow from the country, or the speculative attacks against the currency board.

Dynamics of credit growth rate is often identified with the bank's total loan portfolio in the country which is what residents and businesses borrowed. If loans become poor quality because of financial crisis, the deterioration in banks' loan portfolio could lead to banking crises in the country. Meanwhile, decreasing the total loan portfolio in the country means that is issued less loan than the backed - this often means reduced economic activity.

Credit market developments in the country $\left(Y_{\text {icm }}\right)$ are analysed in two ways - interest rates and general commercial banking loan portfolio shift. Interest rates are analysed as interest rates change from pre financial crisis average. The interest rate reflects the average commercial bank lending interest rates. If during the period no data on commercial banks' loan interest can be found, can be used other indicators that reflect the cost of credit to businesses and residents in the country. This can be a corporate bond yield dynamics, because, according to the Efficient Market Hypothesis, the same risks to subjects must be reflected in the same interest rate, in this case, both the bond and bank credit interest rates should be the same. To assess the impact should be calculated pre financial crisis, interest rates and a post financial crisis (five years after its start), the interest rate differential. If interest rates increase, the value is summed up. The index assessment taken into account only credit resource availability depreciation. The index value named $-Y_{i r}$. Total commercial banks' loan portfolio can be analysed as a pre-crisis loan portfolio and post-crisis loan portfolio within five years after the financial crisis start, the percentage difference. If the loan portfolio increased during the financial crisis is taken at the peak reached at the end of the year. The index value identifies $Y_{I C}$. 
According to, Danilenko (2009) statistical indicators', enabling to see the stock market dynamics and trends, is an equity indexes. According to Leipus et al. (2003), Boreika (2009) the relationship between stock prices and the country's macroeconomic indicators are widely analysed in the literature. Share price index decline is often seen as an early warning signal of financial crisis. Continuing financial crisis, stock prices continued to decrease. However, the stock price index and is considered one of the first signs of economic recovery. Stock market index change can be seen as the local stock market index of the peak before the financial crisis (or at financial crisis) and index a local minimum after financial crisis, which as a drop from the highest point of the former before the financial crisis began. If the stock market index remained unchanged during the financial crisis, the assessment rate is not calculated, the index equal to zero. Since this change is often very high - and often reach $90 \%$, a change in its assessment of the total weight of the index must be minimized ie multiplied by $1 / 5$ ( $1 \%$ drop in the stock market index will be equal to $0.2 \%$ annual GDP growth rate of decline). If this is not done, then we have an incomplete index size, during financial crisis, the most economic indicators don't change, and the strong stock market decline, could lead to very high total index $\left(X_{F K P E}\right)$. This indicator is identified $Y_{\text {ism }}$.

In assessing the state of the national budget can be calculated five years post financial crisis and before the financial crisis in the former state budget balance difference. If a country before the financial crisis had a surplus, will be simply summed deficit values. If, during these five years, at least one year, the country had a budget deficit, which was lower than before the financial crisis, it will not be included in the total sum. The fiscal balance indicator is identified as Yid.

Summary of information about the financial crisis impact on the country's economy index calculation and its components are provided in the first table.

\section{Assessment of reliability of financial crisis impact on the country economy index}

The worst economic crisis in the history of finance is considered "The Great Depression (GD) (1930 crisis), which took place in the USA" (Krugman, 2009; Bernanke, 1983). In order to determine the optimal use of financial crisis impact on the country economy index was calculate the GD index value in the first table, all the indicators of this crisis by the data. The calculations showed in Tables 2-3. The result is that the index value $X_{F K P E}=402.19 X_{F K P E}$ considered reliable, which can be compared with each other outside, inside, comprehensive, national, regional and global financial crises.

Table 1. The financial crisis impact on the country's economy index, calculation algorithm and its component parts

\begin{tabular}{|c|c|}
\hline Indicators & Indicators value \\
\hline Financial crisis impact on the country's economy index & $X_{\text {FKPF }}$ \\
\hline Calculation of financial crisis impact on the country's economy index & $X_{F K P F}=Y_{I B L P}+Y_{i l w n}+Y_{i i}+Y_{i e s d}+Y_{i c m}+1 / 5 Y_{i s w}+Y_{i d d}$ \\
\hline \multicolumn{2}{|c|}{ Sub-indexes of financial crisis impact on the country's economy index } \\
\hline Financial crisis impact on GDP & $Y_{I B L P}$ \\
\hline Financial crisis impact on unemployment & $Y_{i \mu}$ \\
\hline Financial crisis impact on net wages & $Y_{\text {in }}$ \\
\hline Financial crisis impact on labour market & $Y_{i l n}=Y_{i w n}+Y_{i \omega}$ \\
\hline Financial crisis impact on price stability (inflation) & $Y_{i i}$ \\
\hline Financial crisis impact on current account balance & $Y_{i e}$ \\
\hline Financial crisis impact on interest rates & $Y_{i r}$ \\
\hline Financial crisis impact on country's banks' loan portfolio & $Y_{i c}$ \\
\hline Financial crisis impact on credit market & $Y_{i c m}=Y_{i r}+Y_{i c}$ \\
\hline Financial crisis impact on stock market & $Y_{i s m}$ \\
\hline Financial crisis impact on budget balance & $Y_{i d r}$ \\
\hline
\end{tabular}

Source: the authors' conclusion 
Table 2. The Great Depression impact on U.S. economy index calculation

\begin{tabular}{|l|l|l|l|l|l|l|l|l|}
\hline Year & $\begin{array}{c}\text { GDP } \\
\text { U.S. mIn. }\end{array}$ & $\begin{array}{c}\text { GDP } \\
\text { forecast }\end{array}$ & Difference & $\begin{array}{c}\text { Difference } \\
\text { as perc. of } \\
\text { GDP }\end{array}$ & $\begin{array}{c}\text { Curent } \\
\text { Acount } \\
\text { balance as } \\
\text { GDP perc. }\end{array}$ & $\begin{array}{c}\text { Difference } \\
\text { perc. }\end{array}$ & $\begin{array}{c}\text { Budget } \\
\text { deficit }\end{array}$ & $\begin{array}{c}\text { Stock } \\
\text { market } \\
\text { price }\end{array}$ \\
\hline 1929 & 1302 & 1302 & 0 & & -1.35 & 0 & -0.46 & 251.08 \\
\hline 1930 & 1176 & 1234.32 & -8.3218 & 4.96 & -1.51 & -0.16 & -0.96 & 199.59 \\
\hline 1931 & 1081 & 1253.82 & -172.825 & 15.99 & -1.60 & -0.25 & 0.17 & 125.09 \\
\hline 1932 & 925 & 1273.96 & -348.969 & 37.73 & -1.73 & -0.38 & 2.78 & 57.81 \\
\hline 1933 & 937 & 1295.04 & -358.042 & 38.21 & -1.94 & -0.59 & 3.27 & 74.63 \\
\hline 1934 & 1302 & 1302 & -255.782 & 24.11 & -1.51 & -0.16 & 3.11 & 85.52 \\
\hline & & & $Y_{I B V P}=$ & 120.99 & $Y_{\text {iesd }}=$ & 1.53 & $Y_{i d}=9,33$ & $Y_{\text {ism }}=76,7$ \\
\hline
\end{tabular}

Source: the authors' calculation

Table 3. The Great Depression impact on U.S. economy index calculation

\begin{tabular}{|l|l|l|l|l|l|l|l|l|l|l|}
\hline Year & $\begin{array}{c}\text { Unem- } \\
\text { ploy- } \\
\text { ment } \\
\text { rate }\end{array}$ & $\begin{array}{c}\text { Differ- } \\
\text { ence }\end{array}$ & $\begin{array}{c}\text { Wages } \\
\text { index }\end{array}$ & $\begin{array}{c}\text { Differ- } \\
\text { ence }\end{array}$ & $\begin{array}{c}\text { Interest } \\
\text { rates* }\end{array}$ & $\begin{array}{c}\text { Differ- } \\
\text { ence }\end{array}$ & $\begin{array}{c}\text { Loans } \\
\text { (mIn } \\
\text { USD) }\end{array}$ & & Inflation & $\begin{array}{c}\text { Differ- } \\
\text { ence }\end{array}$ \\
\hline $\begin{array}{l}1925- \\
1929\end{array}$ & 4.01 & 0 & 103 & 0 & 4.75 & 0 & 11592.2 & MAX & -0.5 & 0 \\
\hline 1930 & 8.67 & 4.66 & 103.2 & 0.2 & 4.71 & -0.04 & 7677.0 & & -6.4 & 5.9 \\
\hline 1931 & 15.82 & 11.81 & 97.7 & -5.3 & 6.13 & 1.38 & 4022.9 & & -9.3 & 8.8 \\
\hline 1932 & 25.53 & 21.52 & 83.8 & -19.2 & 6.21 & 1.46 & 1730.3 & & -10.3 & 9.8 \\
\hline 1933 & 24.75 & 20.74 & 80.2 & -22.8 & 5.88 & 1.13 & 1053.7 & MIN & 0.8 & -1.3 \\
\hline 1934 & 21.60 & 17.59 & 91.0 & -12 & 4.69 & -0.06 & 2212.3 & & 1.5 & -2 \\
\hline & $Y_{i w}$ & 76.32 & $Y_{i w}$ & 59.3 & $Y_{i r}$ & 3.97 & $Y_{i c}$ & 90.91 & $Y_{i i}$ & 24.5 \\
\hline$X_{F K P E}$ & & &
\end{tabular}

Source: the authors' calculation

In Table 3, the index calculations encountered this problem:

*The average interbank interest rates over the period were not counted, but in the meantime, companies bond yield reflects the opportunity for companies to borrow, so calculations uses average bond yield for the company. This calculation is based on the efficient market hypothesis and the arbitrage principle, which assumes that the bank borrowing rate should be similar or the trends are similar.

3. The financial crisis that affected the economy of Lithuania indexes comparative analysis of the impact

Lithuanian economy in 1990-2011 were affected by three financial crisis, which, was different. It's:

- The banking crisis, which took place in 1995. Country's internal financial crises.

- Russian financial crisis, which took place in 1998. Currency crises which has affected the surrounding regions.

- The global financial crisis, which took place in 2008. The world problems took place at the same time as Lithuanian real estate bubble burst, and the end of the growth of bank credit. The financial crisis can be considered as a complex financial crisis at the same time as the financial crisis originated in Lithuania and the world (global financial crisis had a negative impact on the economy of Lithuania). 
The logic analysis of financial crises that affected the economy of Lithuania, shows that all crisis were different (different types of financial crises, the crisis is internal, part external). Their impacts on the country's macroeconomic indicators were also different. In order to compare financial crisis we use the financial crisis impact on economy index.

Lithuanian banking crises in 1995. Lithuania due to the unfavourable economic situation, the commercial orientation of banks in the early inflationary profits, rapidly changing economic situation (even several times changed monetary units circulating in Lithuania and other reasons, went bankrupt or were liquidated - a large part of the country's banks. This crisis was led by Lithuanian economy factors: enterprise confused between settlements, depositors panic (which is also one of the reasons for the bankruptcy of the banks), reduced lending, loss of revenue collection, increased the current account deficit, a strong increase in unemployment.

However, the assessment of this financial crisis impact faces challenges: economic situation in Lithuania 1990-1994 was a very unstable: high inflation (hyperinflation reaching limits) Currency uncertain system (before the introduction of the litas and currency board with the U.S. dollar), declining GDP, which began to grow only in 1995 (and this year, as the banking crisis starts). Therefore, it is difficult to assess the financial impact of the crisis to economic indicators.

GDP started to grow in financial crisis, so it is difficult to determine it losses (the calculation assumes that GDP loss is equal to the loss of funds that were needed to restructure the banking sector).

Rise in inflation trends in 1990-1993 were mainly result in economic restructuring and the transition to a market economy (to overcome the price adjustment). However, the introduction of the litas (and then when it currency board with the U.S. dollar), inflation started to decline in 1994-1998 it will continue to decline rapidly, but the financial crisis impact on this decline was not clear, but it is clear that financial crisis was not the main cause of this, so this effect will not be considered.

Interest rates also declined and even then some banks faced with problems - it links to inflation, and a sufficiently large bank competition. But the financial crisis did not affect the interest rate decline, this decline in interest rates link to declining inflation.

Another problem in calculating the financial crisis impact on economy index $\left(X_{F K P E}\right)$ is unstable economic situation, as well as a brief history of Lithuania, so it is difficult to determine the long-term trends in macroeconomic indicators (GDP growth, inflation, unemployment).

The stock exchange in Lithuania was established only in 1995, and in the period 1990-2011 had little value in raising capital for companies, and it is not a viable competition for bank loans.

Banking crisis, which took place in 1995 index and calculating the components at 5-6 tables.

Table 5. The banking crisis that took place in 1995, the Lithuanian economy affect components of the index determination

\begin{tabular}{|l|l|l|l|l|l|l|l|l|}
\hline Year & GDP & GDP loss* & \% GDP & Inflation** & Difference & $\begin{array}{c}\text { Current } \\
\text { account } \\
\text { balance }\end{array}$ & Difference & $\begin{array}{c}\text { Budget } \\
\text { deficits*** }\end{array}$ \\
\hline 1994 & 16904.2 & 0 & & 72.2 & 0 & 2.1 & 0 & 6.5 \\
\hline 1995 & 26924.46 & 1200 & $4.46 \%$ & 39.7 & 0 & 10.2 & 8.1 & 5.1 \\
\hline 1996 & 33706.35 & 1200 & $3.56 \%$ & 24.6 & 0 & 9.2 & 7.1 & 4.6 \\
\hline 1997 & 40514.87 & 1200 & $2.96 \%$ & 8.9 & 0 & 10.2 & 8.1 & 1.6 \\
\hline 1998 & 45016.22 & 1200 & $2.67 \%$ & 5.1 & 0 & 12.1 & 10 & 4.6 \\
\hline 1999 & 43885.44 & 1200 & $2.73 \%$ & 0.7 & 0 & 11.2 & 9.1 & 7.8 \\
\hline & & $Y_{\text {IBVP }}$ & 16.38 & $Y_{i i}$ & 0 & $Y_{\text {iesd }}$ & 42.4 & 11.3 \\
\hline
\end{tabular}

Source: the authors' calculation 
Table 6. The banking crisis that took place in 1995 ,

the Lithuanian economy affect components of the index determination and assessment

\begin{tabular}{|l|l|l|l|l|l|l|l|l|}
\hline Year & $\begin{array}{c}\text { Unemployment } \\
\text { rate }\end{array}$ & Difference & Net wages & Difference & $\begin{array}{c}\text { Interest } \\
\text { rates }\end{array}$ & Difference & $\begin{array}{c}\text { Loans } \\
\text { (mln Lt.) }\end{array}$ & \\
\hline 1994 & 3.6 & 2.5 & 266.7 & & 29.81 & 0 & 4205.4 & \\
\hline 1995 & 6.1 & 3.5 & 362.6 & 95.9 & 23.88 & 0 & 4652.5 & MAX \\
\hline 1996 & 7.1 & 2.3 & 466.7 & 200 & 16.00 & 0 & 4393.9 & MIN \\
\hline 1997 & 5.9 & 2.8 & 576.6 & 309.9 & 11.93 & 0 & 4929.9 & \\
\hline 1998 & 6.4 & 4.8 & 683.7 & 417 & 12.57 & 0 & 6939.0 & \\
\hline 1999 & 8.4 & 2.5 & 722.4 & 455.7 & 12.98 & 0 & 7457.1 & \\
\hline & $Y_{\text {iw }}$ & 15.9 & $Y_{i w}$ & 0 & $Y_{i r}$ & 0 & $Y_{i c}$ & 5.56 \\
\hline$X_{\text {FKPF }}=$
\end{tabular}

Source: the authors' calculation

In Tables 5-6 comparability index calculations encountered the following problems:

* The GDP dropped significantly in 1990-1993 due to the economic transition to a market economy, and it began to rise only in 1994-1995 (this does not directly lead to the banking crisis) it is difficult to determine the negative banking crisis impact on the country's economy. In this case, restructuring the banking sector has cost the State of Lithuania 1.2 billion litas. This figure is considered as direct loss of GDP. Thus, it is assumed that if the banking crisis does not come, Lithuania's GDP would have been bigeer 1.2 billion lt. every year.

** Inflationary trends in Lithuania was driven by curency exchange rate changes, and economic stabilization. The banking crisis has had an effect, but it was not significant, so financial crisis impact on inflation in the calculation of the index is equal to 0 .

*** While calculating the financial crisis impact on the budget deficit should be used pre crisis deficit level, but in this case, such a provision is not appropriate. Before the critical years of 1993-1994 budget deficit has been associated with structural reforms in the transition to a market economy, while the budgets for the year 1995-1997 has been planned to be balanced, but the freezing corporate funds in banks, and the erosion of the banks paid income taxes (due to losses and provisions), the state budget faced with problems (failure to collect taxes). Meanwhile, the budget deficit in 1998-1999 is related to the problems of the Russian financial crisis. The consequences of the banking crisis have been resolved since 1997 when the deficit fell sharply. The calculation of the banking crisis in 1995-1997 summed up the impact of the budget deficit.

Russian financial crisis of 1998. In 1998, Russia devaluated its currency (the ruble), and this had a negative impact on the linked countries. However, the Russian financial crisis began, did not cause the country's financial crisis (this is because the financial relations with Russia was not strong; banks did not invest their capital there). Therefore, it cannot be considered an internal crisis. In 1998, the Russian ruble devaluation caused a strong reduction of Lithuania's exports, but it had little influence on the current account deficit. While in 1998-1999 the impact was small, but in 2000 the current account deficit began to decline rapidly, cause of readjustment of the export to other markets (Western Europe). 1998 starts with economic slowdown (the economy declined only in 1999) and this had a negative effect on unemployment rate. Sharp drop in inflation, has increased the state budget deficit. 2000 (in comparison) decreased commercial banks loans portfolio.

Russian financial crisis, which took place in 1998 and the calculation of the index components are showen in 7-8 tables. 
Table 7 Russian financial crisis, which took place in 1998,

the Lithuanian economy affect components of the index determination

\begin{tabular}{|l|l|l|l|l|l|l|l|l|l|}
\hline Year & GDP & $\begin{array}{c}\text { Difference } \\
\text { compared } \\
\text { to forecast }\end{array}$ & $\begin{array}{c}\text { \% of } \\
\text { GDP }\end{array}$ & Inflation & Difference & $\begin{array}{l}\text { Current } \\
\text { account }\end{array}$ & Difference & $\begin{array}{c}\text { Budget } \\
\text { deficit }\end{array}$ & Difference \\
\hline 1997 & 40514.87 & & & 8.9 & & -9.8 & & 1.6 & \\
\hline 1998 & 45016.22 & 1144.71 & 2.54 & 5.1 & 0 & -11.6 & -1.8 & 4.6 & 3 \\
\hline 1999 & 43885.44 & 4369.97 & 9.96 & 0.7 & -4.4 & -10.9 & -1.1 & 7.8 & 6.2 \\
\hline 2000 & 45736.77 & 10161.55 & 22.22 & 1.0 & -4.1 & -5.9 & 3.9 & 2.8 & 1.2 \\
\hline 2001 & 48636.93 & 13277.13 & 27.30 & 1.3 & -3.8 & -4.7 & 5.1 & 1.4 & -0.2 \\
\hline 2002 & 52070.03 & 15990.35 & 30.71 & 0.3 & -4.8 & -5.1 & 4.7 & 1.8 & 0.2 \\
\hline & & $Y_{I B V P}$ & 92.73 & $Y_{i i}$ & 17.1 & $Y_{\text {iesd }}$ & 2.9 & $Y_{i d}$ & 10.6 \\
\hline
\end{tabular}

Source: the authors' calculation

Table 8. Russian financial crisis, which took place in 1998,

the Lithuanian economy affect components of the index and the index of determination

\begin{tabular}{|l|l|l|l|l|l|l|l|l|}
\hline Year & Unemployment & Difference & $\begin{array}{c}\text { Net } \\
\text { wages }\end{array}$ & Difference & $\begin{array}{c}\text { Interest } \\
\text { rates }\end{array}$ & Difference & $\begin{array}{c}\text { Loans } \\
\text { (mIn. Lt) }\end{array}$ & \\
\hline 1997 & 5.4 & & 576.6 & & 11.93 & & 4929.9 & \\
\hline 1998 & 6.4 & 1 & 683.7 & & 12.57 & 0.64 & 6939.0 & \\
\hline 1999 & 8.4 & 3 & 722.4 & & 12.98 & 1.05 & 7457.1 & MAX \\
\hline 2000 & 11.5 & 6.1 & 692.2 & $-4.36 \%$ & 11.03 & -0.9 & 7291.5 & MIN \\
\hline 2001 & 12.5 & 7.1 & 699.4 & $-3.29 \%$ & 8.13 & -3.8 & 8456.2 & \\
\hline 2002 & 13.8 & 8.4 & 728.4 & & 6.08 & -5.85 & 10081.5 & \\
\hline & $Y_{\text {iun }}$ & 25.6 & $Y_{i w}$ & 7.65 & $Y_{i r}$ & 1.69 & $Y_{i c}$ & 2.22 \\
\hline$X_{\text {F KPE }}=$ & $92.73+33.25+17.1+2.9+3.91+1 / 5(56.1)+10.6=171.71$ & \\
\hline
\end{tabular}

Source: the authors' calculation

The global financial crisis in 2008. The complex financial crisis has had a strong negative impact on a number of macroeconomic indicators. Strong GDP decline, the unemployment rate reached its highest level during the 1990-2011 period. Inflation was fluctuating (in financial crises beginning in 2008 it grew. Due to unfavourable trends in world commodity markets, and then strongly decreased). Sharp drop in commercial banks' loan portfolio, increasing the interest rate on newly issued loans in litas (and thus reduced overall credit availability), increased the budget deficit.

Global financial crisis that took place in 2008 index components calculation is shown Tables 9-10.

Table 9. Global financial crisis, in 2008, the impact on Lithuanian economy index determination

\begin{tabular}{|l|l|l|l|l|l|l|l|l|l|}
\hline Year & GDP & $\begin{array}{c}\text { Difference } \\
\text { compared } \\
\text { to forecast }\end{array}$ & $\begin{array}{c}\text { \% of } \\
\text { GDP }\end{array}$ & Inflation & Difference & $\begin{array}{c}\text { Current } \\
\text { account } \\
\text { balance }\end{array}$ & Difference & $\begin{array}{c}\text { Budget } \\
\text { deficit }\end{array}$ & Difference \\
\hline 2007 & 98669.12 & & & 4.1 & 0 & -14.5 & 0 & 0.3 & 0 \\
\hline 2008 & 111482.6 & 0 & 0 & 11.1 & 7 & -13.1 & 1.4 & 4.2 & 3.9 \\
\hline 2009 & 91525.92 & 19399.18 & $21.20 \%$ & 4.2 & 0.1 & 4.3 & 18.8 & 9.7 & 9.4 \\
\hline 2010 & 94625.33 & 26982.77 & $28.52 \%$ & 1.2 & 2.9 & 1.8 & 16.3 & 7.7 & 7.4 \\
\hline 2011 & 112355.3 & 20137.66 & $17.92 \%$ & 3.3 & 0.8 & - & - & 5.8 & 5.5 \\
\hline 2012 & 119444.5 & 23738.93 & $19.87 \%$ & 3.3 & 0.8 & - & - & 2.8 & 2.5 \\
\hline & & $Y_{\text {IBVP }}$ & 87.51 & $Y_{i i}$ & 11.51 & $Y_{\text {iesd }}$ & 0 & $Y_{i d}$ & 28.7 \\
\hline
\end{tabular}

Source: the authors' calculation 
Table 10. Global financial crisis 2008, the impact on the economy components and index determination

\begin{tabular}{|c|c|c|c|c|c|c|c|c|c|}
\hline Year & $\begin{array}{c}\text { Unem- } \\
\text { ployment }\end{array}$ & Difference & $\begin{array}{c}\text { Net } \\
\text { wages }\end{array}$ & $\begin{array}{c}\text { Difference } \\
(\%)\end{array}$ & $\begin{array}{l}\text { Interest } \\
\text { rates }\end{array}$ & Difference & $\begin{array}{l}\text { Loans } \\
\text { (mln Lt) }\end{array}$ & Difference & $\begin{array}{l}\text { OMX } \\
\text { Vilnius } \\
\text { stock } \\
\text { exchange } \\
\text { index }\end{array}$ \\
\hline 2007 & 6,1 & & 1351.9 & & 6.75 & & 64214.6 & & 591.44 \\
\hline 2008 & 5.8 & -0.3 & 1650.9 & & 10.64 & 3.89 & 74806.0 & & 172.71 \\
\hline 2009 & 13.7 & 7.6 & 1602.0 & -3.05 & 13.49 & 6.74 & 67855.0 & & 151.40 \\
\hline 2010 & 17.8 & 11.7 & 1553.8 & -6.25 & 11.35 & 4.6 & 66095.3 & & 261.69 \\
\hline 2011 & 14.9 & 8.8 & 1611.3 & -2.46 & 8.71 & 1.96 & 64743.6 & 13.45 & - \\
\hline 2012 & 11.5 & 5.4 & 1722.4 & 4.15 & - & 0 & - & & - \\
\hline & $Y_{i \mu}$ & 33.5 & $Y_{\text {in }}$ & 11.76 & $Y_{i}$ & 17.19 & $\mathrm{Y}_{\mathrm{ic}}$ & 13.45 & 74.4 \\
\hline$X_{F K P E}=$ & \multicolumn{9}{|c|}{$87.51+45.26+11.51+0+30.64+1 / 5(74.4)+28.7=218.5$} \\
\hline
\end{tabular}

Source: the authors' calculation

As can be seen from Tables 9-10, the Lithuanian economy was strongest affected by a complex financial crisis in 2008. The financial impact of the crisis index $\left(X_{F K P E}\right)$ is as high as 218.5. Russian financial crisis impact index is 171.71. Meanwhile, the least affected by the the banking crisis. Financial crisis impact on the economy index is 91.54. 1930, the U.S. Great Depression affect on the U.S. index was 402.19.

Analysing the financial crisis can be seen the different effects of financial crisis, but Russia and the global financial crisis are quite similar (Fig. 1). The most damage this crisis has made to the prospects for GDP growth ( $54 \%$ of the total index and $40.05 \%$ ). The banking crisis impact on GDP growth outlook was 16.38 (17.98\% of the total impact of the crisis).

These financial crises had a significant impact on GDP growth due to the fact that GDP growth before these financial crises was very high (before the Russian financial crisis, GDP growth reached $7.3 \%$, and before the global financial crisis - $9.8 \%$ ). After financial crises the GDP fell (in 1999 and 2009) because this indicator has reached very high values, before. It is also possible to see a tendency that Lithuanian GDP growth is not stable, it tends to grow strongly, as well as a significant decline.

Comparing all financial crises is noted that all financial crises had major impact on (Fig. 1) labour market $\left(Y_{i l m}\right)$. Its values compared to all index were: the banking crisis, $17.36 \%$ the Russian financial crisis $19.36 \%$; global financial crisis, $20.71 \%$. There is also a significant impact on the budget balance: (Fig. 1). $12.34 \%$ during the banking crisis, $6.17 \%$ during the Russian financial crisis, $13.14 \%$ during the global financial crisis.

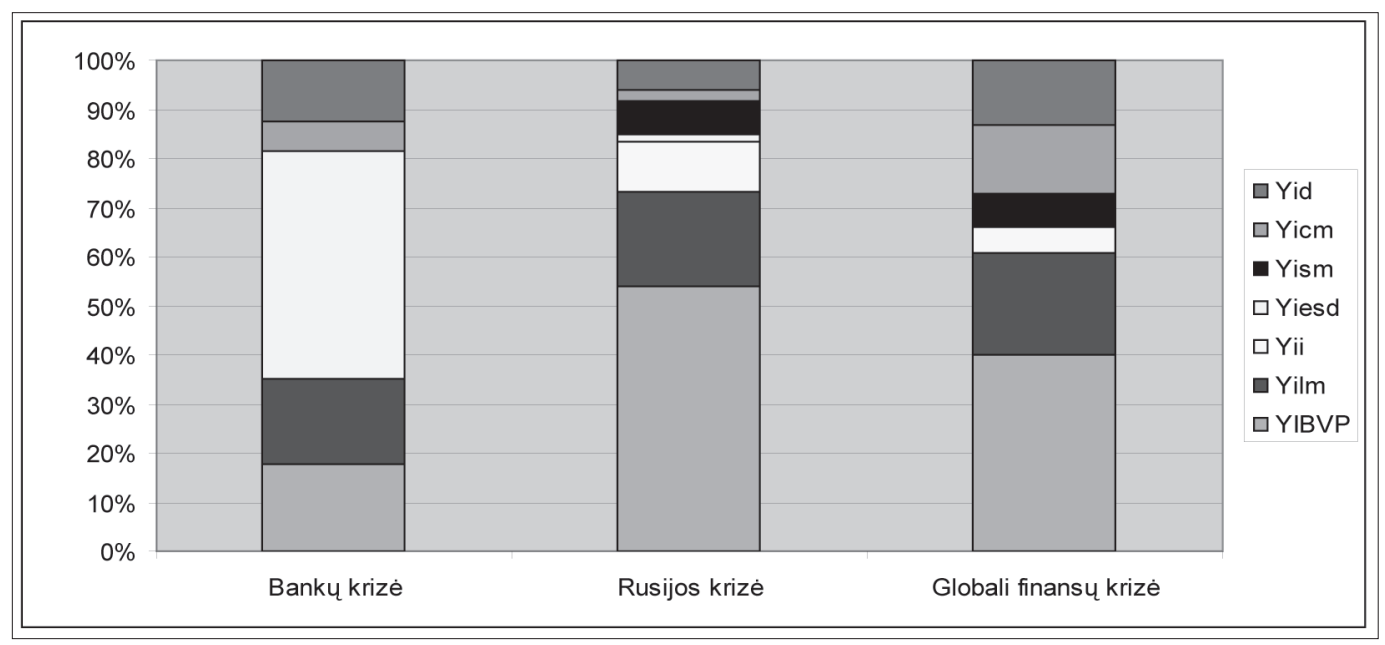

Figure 1. Financial crises impact on Lithuanian economy component distribution Source: the authors' calculation 
Inflationary trends during financial crises in Lithuania were not strongly affected: the Russian financial crisis reached 17.1 (9.95\% of the total financial crisis impact), the global financial crisis, 11.51 (5.2\% of the total financial crisis impact). So we can say that the financial crises had little impact on price stability. Lithuania did not cause the financial crisis with very high inflation, or prolonged deflation.

Analysing financial crises impact on the country's stock market we see that Lithuania's share price indices reflecting the decline during the crisis was hit seriously (during Russian financial crisis, index fell $56.1 \%$, during global financial crisis it fell $74.4 \%$ ). During bank crisis in 1995, the stock market index has not yet been calculated, and the National Stock Exchange was at an early stage of creation.

Meanwhile, the financial crisis impact on the current account deficit and the credit market was different. During the banking crisis impact on the current account deficit was very high (42.4 points or $46.3 \%$ of the total impact of the crisis), while during the Russian crisis and the global financial crisis negative impact was small or none at all. During Russian crisis, the effects was $2.9 \%$ of impact, during the global financial crisis it had no impact (current account had deficit, but during the crisis reached a surplus).

Financial crises impacts on credit markets $\left(Y_{i c m}\right)$ were different, the banking crisis and the Russian financial crisis impacts were small, respectively 5.56 and 3.91. Meanwhile, the global financial crisis, this effect was 30.64 (14.02\% of the total financial impact of the crisis). This can be explained by the fact that the banks' effect on economy growth in 2005-2007, and after global financial crisis was much higher than in other crises, the loan portfolio was high, there has been extensive growth in the loan portfolio in 2003-2007, while the interest rates in 2007 was the lowest during the 20 -year period, and the global turmoil that started in real estate sector reached banks sector quickly and have been strongly affected by the global credit markets. Meanwhile, during banking and Russian financial crises, credit market turmoil was not large. During banking crisis loans portfolio was still very low and the interest rates was high (and therefore, even at crisis, have fallen), while during Russian financial crisis, interest rates changed only slightly, while the loan portfolio maintained almost the same.

\section{Conclusions}

In the scientific literature, there is lack of methodology for comparing the financial crisis negative impact on economy. In terms of specific financial crisis impact on the economy, or comparing impact on different countries or at different times are not any methods to compare the negative effects. It was concluded to make a financial crisis impact on economy. This index helps to compare the different financial crises in different countries by combining all the negative impact "parts".

This index values reliability can be compared with calculated U.S. "The Great Depression 1930 financial crisis index value -402.19 .

Analysing the economic development of Lithuania in 1990-2011 identified three financial crises that affected the country's economy. Banking Crisis (1995) - is an internal banking crisis. Russian financial crisis (1998) - external currency and debt crises. The global financial crisis (2008) - a complex global financial (real estate bubble, debt crisis, banking crisis) crisis. Was calculated index to compare impact of these crises on country's economy. In summary, all of financial crises affected the economy of Lithuania in different ways, but the calculation of the financial crisis impact on the country's economic index suggest that the greatest impact on the economy of Lithuania was made by global financial crisis (2008) - index value 218.5. Similar in many ways, but much less impact was made by the Russian financial crisis (1998) - index value 171.71. The banking crisis (1995) had the lowest impact on economy, index value 91.54. None of the financial crisis impact on the Lithuanian economy was greater than the Great Depression impact on the U.S. economy. All financial crises had a major effect on GDP growth, labour market, and budget balance. The impact on the stock market was also similar, it fell more than $50 \%$ during the Russian financial crisis and the global financial crisis. Impact on inflation was small, because the crisis has been associated with high inflation or high deflation. Meanwhile, the impacts on current account deficit and the credit market had been different and related to the specifics of the individual crisis. The current account balance was most negatively 
affected by the banking crisis (1995). Banking crisis affected the current account deficit, while the other did not. A credit market was significantly impacted by global financial crisis (2008), while other crises, negative effect were not significant.

\section{References}

Bernanke, B. (1983). Non-Monetary Effects of the Financial Crisis in the Propagation of the Great Depression. The American Economic Review, Vol. 73 [Interactive]. Access the Internet: <http://www.nber.org/papers/w1054>.

Boreika, P., Pilinkus, D. (2009). Macroeconomic indicators and stock price correlation between the Baltic countries. Economics and Management, Vol. 14, p. 692-699.

Danilenko, S. (2009). Macroeconomic processes affect the stock market survey. Economics and Management, Vol. 14, p. 731-736.

Daraškevičiūtè, B., Glinskienė, R., Lapinskienè, D. (2007). The Peculiarities of Lithuania's Export in the Context of Integration to the European Union. Economics and Management, Vol. 12, p. 721-727.

Deksnytė, I., Pukelienè, V. (2010). Currency crisis on the economies of: Russia and the repercussions of the case in Lithuania. Applied Economics: systematic Research, Vol. 4 (1), p. 151-165.

FRB Monthly Review [interactive]. Access the Internet $<$ http://fraser.stlouisfed.org/publication/?pid=62>.

FRB Monthly Review [interactive]. Access the Internet: <http://fraser.stlouisfed.org/docs/publications/FRB/1920s/ frb_121929.pdf>.

Harvey, T. J. (2010). Modeling financial crises: a schematic approach. Journal of Post Keynesian Economics, Vol. 33 (1), p. 61-82.

Krugman, P. (2008). The Return of Depresion Economics and The crisis of 2008. London: Penguin books.

Krugman, P. (2003). A model of balance of payment crises. Journal of money, credit \& banking, Vol. 11 (3), p. 311-325.

Kuodis, R. (2008). Lithuanian economic transformation of the 1990-2008 year: Phases and major economic policy errors. Monetary Studies, Vol. 2, p. 97-98.

Leipus, R., Norvaiša, R. (2003). Financial market theory. Monetary Studies, Vol. 4, p. 5-28.

Bank of Lithuania. (1996). 1995 Annual Report. Vilnius: Bank of Lithuania.

Bank of Lithuania. (1997). 1996 Annual Report. Vilnius: Bank of Lithuania.

Bank of Lithuania. (1998). 1997 Annual Report. Vilnius: Bank of Lithuania.

Bank of Lithuania. (1999). 1998 Annual Report. Vilnius: Bank of Lithuania.

Lithuanian banks Database [interactive]. Access the Internet: <http://www.lb.lt/pinigu_finansiniu_instituciju_paskolu_ir_indeliu_palukanu_normu_statistika) $>$.

Mishkin, F. (1992). Anatomy of a Financial Crisis. Journal of Evolutionary Economics, Vol. 2, p. 115-130 [interactive]. Access the Internet: $<$ http://www.nber.org/papers/w3934>.

Račickas, E., Vasiliauskaite, A. (2010). Global financial crisis and its impact on Lithuania economy. Economics and Management, Vol. 15, p. 1006-1017.

Sachs, J., Tornell, A., Velasco, A. (1996). Financial crises in emerging markets: The lessons from 1995. Brookings Papers on Economic Activity, Vol. 1 (27), p. 147-199.

Simanavičienè, A., Užkurytè, L. (2009). Changes in the labor market during the economic recession the case of Lithuania. Economics and Management, Vol. 14, p. 940-946.

Department of Statistics to the Government of the Republic of Lithuania [interactive]. Access the Internet: http://www. stat.gov.lt/lt/.

Vetlov, I., Virbickas, E. (2006). Lithuanian labor market flexibility. Monetary Studies, Vol. 1, p. 5-22.

Wyplosz, C. (1998). Globalised financial markets and financial crises. Regulatory and supervisory challenges in New era of global finance. The Hague: Fondad, p. 70-87. 


\title{
LIETUVOS FINANSŲ KRIZIŲ POVEIKIO ŠALIES EKONOMIKAI PALYGINAMASIS TYRIMAS
}

\author{
Deimena Kiyak, Tomas Reichenbachas \\ Klaipėdos universitetas (Lietuva)
}

Santrauka

Akcentuojant darnaus ekonominio vystymosi prielaidas Lietuvoje ir siekiant tyrimu pagrindu kurti regioninę politiką, straipsnyje atliekamas Lietuvoje vykusių finansų krizių poveikio šalies ekonomikai palyginamasis tyrimas. Nors daugelis mokslininkų išskiria nemažai ekonominių rodiklių, kurie paveikti finansų krizių, tačiau vertinant finansų krizių poveikị šalies ekonomikai susiduriama su problemomis, nėra bendro modelio, kaip ìvertinti finansų krizès poveiki šalies ekonomikai, nèra ir metodikos, kaip palyginti ši poveiki su kitų finansų krizių poveikiu šaliai. Finansų krizès poveikiui ịvertinti būtina visas neigiamas poveikio „dalis" sujungti i vieną visuma, t. y. reikia indekso, kuris parodytu, kokio masto neigiamas poveikis ištiko šalies ekonomiką dèl finansų krizès. Toks indeksas padètų palyginti skirtingų tipų finansų krizių poveiki šaliai arba skirtingoms šalims. Siekiant atlikti Lietuvos finansų krizių poveikio šalies ekonomikai palyginamaji tyrimą sudarytas finansų krizių neigiamo poveikio šalies ekonomikai nustatymo palyginamumo indeksas, kuris padeda palyginti skirtingų finansų krizių neigiamą poveiki skirtingoms šalims, nes sujungia visas neigiamo poveikio „dalis“. Sudarytame indekse atsiskleidžia finansų krizės poveikis šalies BVP, nedarbo lygiui, neto darbo užmokesčiui, darbo rinkai, kainų stabilumui (infliacijai), einamosios sąskaitos balansui, palūkanų normoms, bendram komercinių bankų paskolų portfeliui, kredito ir akcijų rinkai, biudžeto balansui. Siekiant patvirtinti sudaryto indekso reikšmès patikimumą ir nustatyti bazinę palyginimo indekso reikšmę, apskaičiuotas pačios didžiausios ekonomikos istorijoje finansų krizès („Didžiosios depresijos“ 1930 metų krizès, ivvykusios JAV) indeksas. Gauta šio indekso reikšmé $X_{F K P E}=402,19$ laikoma patikima, pagal ją galima palyginti tarpusavyje išorès, vidaus, kompleksines, šalies, regiono ir globalias finansų krizes. Nustatyta, kad Lietuvoje 1990-2010 metų laikotarpiu i̇vyko trys Lietuvos ekonomiką neigiamai paveikusios finansų krizès: „Bankų krizė“ (1995) - vidinè šalies finansų krizè, „Rusijos finansų krizė“ (1998) - valiutinė krizė, paveikusi aplinkini regiona, ir „Globali finansų krizé“ (2008), t. y. kompleksiné finansu krizè, vienu metu kilusi tiek Lietuvoje, tiek pasaulyje. Atlikus loginę finansų krizių, paveikusių Lietuvos ekonomiką, analizę, aiškejja, kad visos jos skirtingos (skiriasi finansų krizių tipai: dalis krizių yra vidinės, dalis išorinės). Skiriasi ir jų poveikis šalies makroekonominiams rodikliams. Straipsnyje apibendrinti Lietuvoje vykusių finansų krizių poveikio ekonomikai pagrindiniai veiksniai. „Bankų krizès“ (1995) poveikio Lietuvos ekonomikai pagrindiniai veiksniai: sutrikę įmonių tarpusavio atsiskaitymai, indèlininkų panika (tai pat viena iš dalies bankų bankroto priežasčiu), sumažèjęs kreditavimas ir biudžeto pajamų surinkimas, padidejjęs einamosios sąskaitos deficitas, gerokai išaugęs nedarbas. „Rusijos finansų krizė“ (1998) lèmė struktūrinius Lietuvos tarptautinès prekybos pokyčius. Eksportuotojai pradejjo orientuotis i Vakarų rinkas, o priklausomybė nuo NVS šaliu èmė mažèti. Akcentuotina tai, kad Rusijos finansų krizè nepaveiké Lietuvos finansų sistemos, ir nesukèlè bankinès sistemos krizès Lietuvoje. Finansinis sektorius nepatyrẻ sukrètimų. „Globali finansų krizé“ (2008) neigiamai paveikẻ daugelį makroekonominių rodiklių: gerokai smuko BVP, išaugo nedarbo lygis, kito infliacija, sumažèjo komercinių bankų paskolų portfelis, didejjo palūkanų norma už naujai litais išduotas paskolas, sumažèjo kreditavimo galimybès, padidèjo biudžeto deficitas. Pritaikius sudaryto indekso modeli gautos šios finansų krizių Lietuvoje indeksų reikšmès: globalios finansų krizės (2008) indeksas $\left(X_{F K P E}\right)$ siekia net 218,5, Rusijos finansų krizès (1998) poveikio indeksas - 171,71, tuo tarpu mažiausiai ekonomiką paveikè bankų krizè (1995), nes finansų krizių poveikio ekonomikai indeksas siekia 91,54. Nei vienos finansų krizės poveikis Lietuvos ekonomikai nebuvo didesnis nei Didžiosios depresijos poveikis JAV ekonomikai. Visos vykusios finansų krizès labai paveikè BVP augimą, darbo rinką, valstybės biudžeto balansą. Poveikis akcijų rinkai taip pat buvo panašus, jos smuko daugiau nei 50 \% tiek per Rusijos finansų krizę, tiek per globalią finansų krizę. Infliacijai Lietuvą paveikusios finansų krizès turèjo mažai įtakos, nes šios krizès su didele inf- 
liacija ar defliacija nebuvo susijusios. Tuo tarpu poveikis einamosios sąskaitos deficitui ir kredito rinkai buvo skirtingas ir susijęs su pavienių krizių specifika. Einamosios sąskaitos balansą labiausiai neigiamai paveikẻ „Bankų krizé“ (1995). Ji taip pat smarkiai paveikè einamosios sąskaitos deficita, ko negalima pasakyti apie kitas nagrinètas krizes. Kredito rinkai didelį neigiamą poveikį turèjo globali finansų krizè (2008), tuo tarpu kitu krizių neigiamas poveikis kredito rinkai nebuvo didelis.

PAGRINDINIAI ŽODŽIAI: finansu krizé, finansu krizés indeksas, banku krizé, Rusijos finansu krizé, globali finansu krizé.

JEL KLASIFIKACIJA: G000; G010. 